\title{
Plasmid Transfer in Streptococcus faecalis: Production of Multiple Sex Pheromones by Recipients
}

\author{
Gary M. Dunny, ${ }^{1}$ Ronald A. Craig, Richard L. Carron, and Don B. Clewell \\ The Dental Research Institute, and The Departments of Microbiology and Oral Biology, \\ Schools of Medicine and Dentistry, The University of Michigan, Ann Arbor, Michigan 48109
}

Received December 21, 1978

\begin{abstract}
In a previous report (1978, Proc. Nat. Acad. Sci. USA 75, 3479-3483), we showed that recipient strains of Streptococcus faecalis excrete a heat-stable substance (sex pheromone) which induces donor cells carrying certain conjugative plasmids to become adherent, generating the cell-to-cell contact necessary for plasmid transfer. Since donors themselves could be induced to aggregate or "clump" by recipient filtrates, the substance was referred to as "clumping-inducing agent" (CIA). In this report, wc present a simplified assay for CIA and determine the level of activity in filtrates prepared at various stages of growth. We also present evidence that recipient cells produce multiple pheromones, each specific for donors harboring a particular class of plasmids. Whereas a recipient that acquires a conjugative plasmid no longer produces the corresponding CIA, it still produces CIAs specific for donors with different conjugative plasmids. In addition, an analysis of 100 clinical isolates of $\boldsymbol{S}$. faecalis showed that drug-resistant strains are significantly more likely to respond to and produce CIA activities than drug-sensitive strains. A model is discussed describing the relationships of sex pheromones to the mating process.
\end{abstract}

A number of Streptococcus faecalis strains have been shown to transfer plasmid DNA by a process resembling conjugation. As shown in our laboratory (Dunny and Clewell, 1975; Oliver et al., 1977a) and elsewhere (Tomura et al., 1973; Jacob and Hobbs, 1974; Jacob et al., 1975; Van Embden et al., 1977; Marder and Kayser, 1977) genes determining hemolysins, bacteriocins, bacteriocin sensitivity, and drug resistance are transferable. Transferable plasmids were also shown to mobilize chromosomal markers at low frequency (Franke et al., 1978).

Recently, we reported (Dunny et al., 1978) evidence that recipient strains excrete a soluble, trypsin-sensitive, heat-stable substance which induces donor cells carrying certain conjugative hemolysin plasmids (pAM 11 or pPD1) to become very adherent, a phenomenon presumed to facilitate the formation of mating aggregates resulting from random collisions of these nonmotile cells. Since cell-free filtrates of recipients

' Current address: Department of Agronomy, Cornell University, Ithaca, N. Y. 14853. also elicited an aggregation (or clumping) response when mixed with donors, this substance was referred to as "clumpinginducing agent" (CIA). When recipientfiltrates were mixed with donor cells for 20-50 min prior to a short (10 $\mathrm{min}$ ) mating with recipients, the frequency of plasmid transfer was increased by several orders of magnitude. The response of donor cells to CIA required both RNA and protein synthesis, but not DNA synthesis. CIA thus appeared to represent a bacterial sex pheromone.

In this report we show that recipient cells produce multiple pheromones, each one apparently specific for a particular class of plasmids. We include a simplified assay for CIA activity and establish the optimum time (during cell growth) for preparing this material. An analysis of 100 clinical isolates for response to and production of CIA is also presented, suggesting a possible role of sex pheromones in the evolution of drugresistant bacteria. A model describing the relationships of pheromones to the mating process is discussed. 


\section{MATERIALS AND METHODS}

Strains and materials. The $S$. faecalis strains and relevant plasmids used in this study are described in Tables 1 and 2. The conjugative plasmids studied all determine hemolysins. The conjugative potential of certain hemolysin plasmids was determined by monitoring their mobilization of the nonconjugative plasmid $\mathrm{pAM} \alpha 1$, which carries a selectable tetracycline-resistance $\left(\mathrm{Tc}^{r}\right)$ determinant. Cells were grown in Oxoid Nutrient Broth No. 2 supplemented with $0.2 \%$ glucose and $0.1 \mathrm{M}$ Tris $-\mathrm{HCl}$,

TABLE 1

Strains of $S$. faecalis Used In This Study

\begin{tabular}{|c|c|c|c|}
\hline Strain & Source & $\begin{array}{c}\text { Presence of } \\
\text { conjugative } \\
\text { plasmid }\end{array}$ & Comment \\
\hline $39-5$ & Rosan and Williams, 1964 & + & $\begin{array}{l}\text { Carries pPD1 and three cryptic plasmids } \\
\text { (pPD2, pPD3, pPD4) (Clewell et al., 1979) }\end{array}$ \\
\hline $39-5 S$ & Derived here & + & $\begin{array}{l}\text { Spontaneous mutant, resistant to strepto- } \\
\text { mycin at } 1 \mathrm{mg} / \mathrm{ml}\end{array}$ \\
\hline $39-5 \mathrm{~S} \alpha$ & Derived here & + & $\begin{array}{l}\text { A transconjugant of } 39-5 S \text { into which pAM } \alpha 1 \\
\text { was introduced, displacing pPD4 (appar- } \\
\text { ently pPD4 and pAM } \alpha 1 \text { are incompatible) } \\
\text { (unpublished) }\end{array}$ \\
\hline JH2-2 & Jacob and Hobbs, 1974 & - & $\begin{array}{l}\text { A plasmid-free strain resistant to rifampicin } \\
\text { and fusidic acid }\end{array}$ \\
\hline HD1 & Derived here & + & $\begin{array}{l}\text { A transconjugant of } \mathrm{JH} 2-2 \text { harboring pAM } \gamma 1 \\
\text { (Dunny and Clewell, 1975) }\end{array}$ \\
\hline GD50 & Derived here & + & $\begin{array}{l}\text { A transconjugant of } \mathrm{JH} 2-2 \text { carrying pPD1 } \\
\text { and pPD4 }\end{array}$ \\
\hline GD60 & Derived here & + & A transconjugant of $\mathrm{JH} 2-2$ carrying pOB 1 \\
\hline GD70 & Derived here & + & A transconjugant of JH2-2 carrying pAD1 \\
\hline DS-5C1 & Derived here & + & $\begin{array}{l}\text { Obtained by curing pAM } \beta 1 \text { from strain DS-5 } \\
\text { (Clewell et al., 1974); carries plasmids } \\
\text { pAM } \alpha 1 \text { and pAM } \gamma 1\end{array}$ \\
\hline DS16 & Clinical isolate & + & $\begin{array}{l}\text { From St. Joseph's Mercy Hospital, Ann } \\
\text { Arbor, Mich.; carries pAD1 and pAD2 } \\
\text { (Clewell et al., 1978) }\end{array}$ \\
\hline DS16C1 & Derived here & - & $\begin{array}{l}\text { Obtained by curing pAD1 from strain DS16; } \\
\text { carries pAD2 }\end{array}$ \\
\hline 5952 & Oliver et al., 1977a & + & Carries pOB1 and pOB2 \\
\hline $5952 \mathrm{C} 1$ & Oliver et al., 1977a & - & $\begin{array}{l}\text { Obtained by curing pOB } 1 \text { from strain } 5952 \text {; } \\
\text { carries pOB } 2\end{array}$ \\
\hline OG1-10 & Dunny et al., 1978 & - & $\begin{array}{l}\text { Plasmid free; resistant to streptomycin. A } \\
\text { liquefaciens subspecies }\end{array}$ \\
\hline OG1-12 & Dunny et al., 1978 & + & $\begin{array}{l}\text { A transconjugant of OG1-10 carrying pAM } \alpha 1 \\
\text { and pAM } \gamma 1\end{array}$ \\
\hline OG1-50 & Derived here & + & $\begin{array}{l}\text { A transconjugant of OG1-10 carrying pAD1: } \\
\text { :Tn917 (Tomich et al., 1978) }\end{array}$ \\
\hline OG1-RF1 & Dunny et al., 1978 & - & $\begin{array}{l}\text { Plasmid free; an OG1 strain with spontane- } \\
\text { ous mutations to rifampicin and fusidic } \\
\text { acid }\end{array}$ \\
\hline ND539 & Wagner, 1973 & - & $\begin{array}{l}\text { A liquefaciens subspecies; harbors pAM539 } \\
\quad \text { (Oliver et al., 1977b) }\end{array}$ \\
\hline DR 1 & Clinical isolate & - & $\begin{array}{l}\text { A plasmid-free strain from St. Joseph's } \\
\text { Mercy Hospital, Ann Arbor, Mich. }\end{array}$ \\
\hline
\end{tabular}


TABLE 2

Relevant Plasmids Used in This Study

\begin{tabular}{lcll}
\hline \multicolumn{1}{c}{ Plasmid } & $\begin{array}{c}\text { Molecular wcight } \\
\left(\times 10^{7}\right)\end{array}$ & \multicolumn{1}{c}{ Related phenotype } & Source \\
\hline pAM $\gamma 1$ & 3.5 & Hemolysin, conjugative & DS-5C1 \\
pPD1 & 3.5 & Hemolysin, conjugative & $39-5$ \\
pOB 1 & 4.6 & Hemolysin, conjugative & 5952 \\
pAD1 & 3.5 & Hemolysin, conjugative & DS16 \\
pAD1::Tn917 & 3.8 & Hemolysin, erythromycin resistant, conjugative & DS16 \\
pAM $\alpha 1$ & 0.6 & Tetracycline resistant, nonconjugative & DS-5C1 \\
\hline
\end{tabular}

pH $7.7(\mathrm{~N} 2 \mathrm{G} \Gamma)$. Cultures were grown at $37^{\circ} \mathrm{C}$ with gentle shaking.

Other materials and their sources were as previously described (Dunny and Clewell, 1975; Dunny et al., 1978).

CIA assay. Unless otherwise indicated in the text, CIA preparations were made from cultures which were one or two generations prior to entry into stationary phase. Cells were then pelleted by centrifugation, and the supernatant was filtered through a Millipore filter $(0.22-\mu \mathrm{m}$ pore size). The resulting filtrates were generally autoclaved for $20 \mathrm{~min}$, to "stabilize" the CIA activity, and stored at $4^{\circ} \mathrm{C}$. A microtiter system was used for the quantitation of CIA using appropriate "responder cells" (i.e., cells harboring an appropriate conjugative plasmid). Filtrates were added to Cooke microtiter "U' -shaped plates and serially diluted (two-fold) into fresh N2GT using $0.05-\mathrm{ml}$
Cooke microdiluters. Responder cells from early stationary phase diluted to $A_{660}$ of 0.500 in fresh N2GT were then added to each well using a $0.05-\mathrm{ml}$ Cooke pipet dropper. The titer was read 90-120 min after incubation at $37^{\circ} \mathrm{C}$ on a shaker. An example of the use of this system is shown in Fig. 1, where a series of two-fold dilutions of OG1-10 filtrate are tested for their ability to induce clumping of cells (harboring $\mathrm{pAM} \gamma 1$ and $\mathrm{pAM} \alpha 1)$. Here the CIA activity would be interpreted to have a titer of 16 ; and, as is clearly seen, the "endpoints" are reasonably sharp.

Mating experiments. Matings were carried out using an initial donor:recipient ratio of $1: 10$. For the mating enhancement studies, donor cells were grown to late log phase (approximately $5 \times 10^{8}$ cells $/ \mathrm{ml}$ ) and diluted $1: 10$ into $2 \mathrm{ml}$ of a $1: 1$ mixture of fresh broth and filtrate containing CIA. The cells

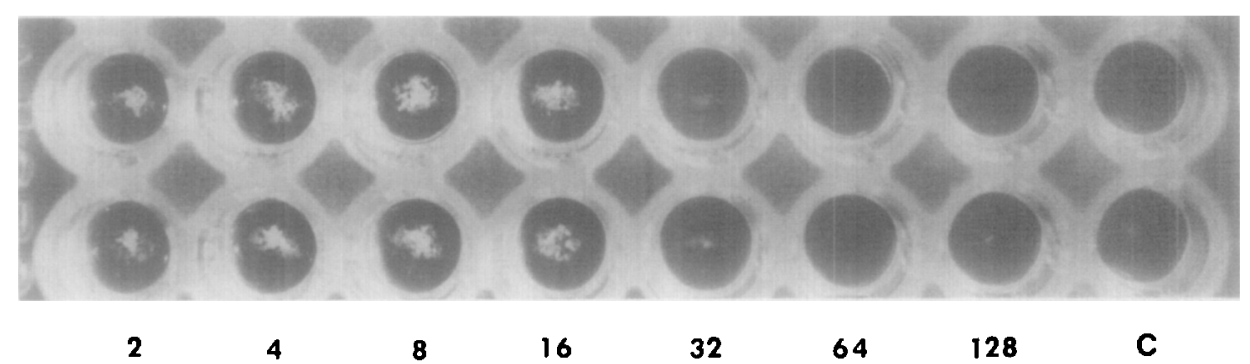

FIG. 1. CIA assay using a microtiter assay as described under Materials and Methods. Duplicate serial twofold dilutions (as indicated) of filtrate (containing CIA) of OG 1-10 cells were tested for their ability to induce clumping in an OG1-RF1 derivative harboring $\mathrm{pAM} \gamma 1$ and $\mathrm{pAM} \alpha 1$. C represents a control using a filtrate of responder cells. Cells that have responded to CIA appear as a floculent material at the bottom of the well. 
were then incubated for $45 \mathrm{~min}$ at $37^{\circ} \mathrm{C}$. A late $\log$ culture of recipient cells was diluted $1: 8$ into fresh broth during the induction of donors; and at the end of the donor induction period, $0.2 \mathrm{ml}$ of the donors were mixed with $1.8 \mathrm{ml}$ of the recipients. After 10 min at $37^{\circ} \mathrm{C}$, the cells were Vortex-mixed and plated on selective media (Difco, Penassay Broth). Drug concentrations in plates were as follows: Rifampicin $(25 \mu \mathrm{g} / \mathrm{ml})$, fusidic acid (25 $\mu \mathrm{g} / \mathrm{ml})$, tetracycline $(5 \mu \mathrm{g} / \mathrm{ml})$, and erythromycin $(50 \mu \mathrm{g} / \mathrm{ml})$.

\section{RESULTS}

The Level of CIA Activity in filtrates as a Function of Cellular Growth

Using the microtiter assay described under Materials and Methods, the level of CIA activity produced by OG1-10 cells and JH2-2 cells (both plasmid free) was determined as a function of growth. Three different responder systems (pPD1, pAM $\gamma 1$, and pAD1::Tn917) were used to determine activity. As shown in Fig. 2, CIA was found to parallel cellular growth during log phase; and as the cells approached stationary phase, the activity reached a maximum. In the case of the OG1-10 cells, activity then decreased logarithmically, whereas with the JH2-2 cells, activity remained relatively constant for several hours. It is likely that the decrease in activity observed for the OG1-10 cells is a result of proteolytic activity which accumulates as the cells enter stationary phase. OG1-10 is a liquefaciens subspecies of $S$. faecalis and thus produces a "gelatinase." ( $\mathrm{JH} 2-2$ is not a liquefaciens subspecies.) Conceivably, this could be involved in the decay of CIA activity. In support of this possibility is our observation that another liquefaciens strain in our collection (ND539) behaves similar to OG110, whereas another "non-liquefaciens" strain (DR1) behaves like JH2-2.

Table 3 shows that filtrates containing maximum CIA activity have significant mating-enhancement activity if exposed to donor cells for $45 \mathrm{~min}$ prior to a short (10

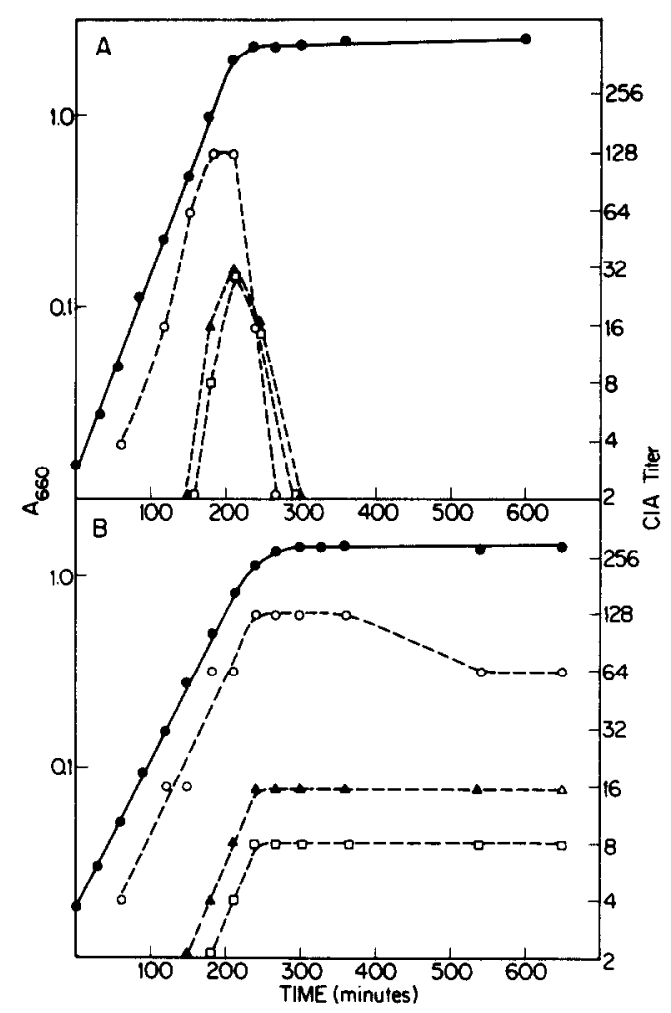

FIG. 2. Measurement of CIA activity in filtrates of OG1-10 (A) and JH2-2 (B) cultures during growth. At the indicated time points aliquots were removed, filtered, autoclaved and tested for CIA activity toward 39-5 (harbors pPD1), O, OG1-12 (harbors pAMy1 and pAM $\alpha 1$ ), $\Delta$, and OG1-50 (harbors pAD1::Tn917), $\square$. The solid line indicates the absorption at $660 \mathrm{~nm}$ indicating the cell density during growth.

min) mating. In all cases, the number of transconjugants increased by several orders of magnitude over the controls. These data are consistent with our previously published data for pPD1 and pAM $\gamma 1$ donors (both monitored by their ability to mobilize the small tetracycline resistance plasmid pAM $\alpha 1)$. pAD1::Tn917 is a hemolysin plasmid (pAD1) onto which a transposable erythromycin element has been introduced (Tomich et al., 1978). With the OG1-10 filtrate, this system shows a $10^{6}$-fold enhancement in mating frequency, with the number of transconjugants appearing as high as $3 \times 10^{-1}$ per donor. The difference between this system and the others may in 
TABLE 3

Mating Enhancement Activity of Filtrates Taken from Late Log and Stationary Phase Cultures of OG1-10 AND JH2-2 $2^{a}$

\begin{tabular}{|c|c|c|c|c|}
\hline Filtrate & Mating $^{b}$ & $\begin{array}{l}\text { Time point }{ }^{a} \\
\quad(\min )\end{array}$ & CIA titer ${ }^{c}$ & Transconjugants per donor \\
\hline \multirow[t]{3}{*}{ OG1-10 } & $\begin{array}{c}39-5 S \alpha \times \text { OG1-RF1 } \\
(\mathrm{pPD} 1)\end{array}$ & $\begin{array}{l}\text { Control } \\
210 \\
600\end{array}$ & $\begin{array}{l}\overline{128} \\
<2\end{array}$ & $\begin{array}{r}<5 \times 10^{-7} \\
2 \times 10^{-3} \\
<5 \times 10^{-7}\end{array}$ \\
\hline & $\begin{array}{c}\text { OG1-12 } 12 \text { OG1-RF1 } \\
(\text { pAM } \gamma 1)\end{array}$ & $\begin{array}{l}\text { Control } \\
210 \\
600\end{array}$ & $\begin{array}{l}- \\
32 \\
<2\end{array}$ & $\begin{array}{r}<4 \times 10^{-7} \\
6 \times 10^{-4} \\
3 \times 10^{-7}\end{array}$ \\
\hline & $\begin{array}{l}\text { OG1-50 } \times \text { OG1-RF1 } \\
(\text { pAD1::Tn917) }\end{array}$ & $\begin{array}{l}\text { Control } \\
210 \\
600\end{array}$ & $\begin{array}{l}\overline{32} \\
<2\end{array}$ & $\begin{array}{l}4 \times 10^{-7} \\
3 \times 10^{-1} \\
4 \times 10^{-7}\end{array}$ \\
\hline \multirow[t]{3}{*}{ JH2-2 } & $\begin{array}{c}39-5 \mathrm{~S} \alpha \times \text { OG1-RF1 } \\
(\mathrm{pPD} 1)\end{array}$ & $\begin{array}{l}\text { Control } \\
270 \\
660\end{array}$ & $\begin{array}{r}\overline{128} \\
64\end{array}$ & $\begin{array}{l}4 \times 10^{-7} \\
2 \times 10^{-3} \\
1 \times 10^{-3}\end{array}$ \\
\hline & $\begin{array}{c}\text { OG1-12 } \times \text { OG1-RF1 } \\
(\text { pAM } \gamma 1)\end{array}$ & $\begin{array}{l}\text { Control } \\
270 \\
660\end{array}$ & $\begin{array}{l}- \\
16 \\
16\end{array}$ & $\begin{array}{l}1 \times 10^{-7} \\
4 \times 10^{-3} \\
2 \times 10^{-3}\end{array}$ \\
\hline & $\begin{array}{l}\text { OG1-50 } \times \text { OG1-RF1 } \\
\quad(\text { pAD1::Tn917) }\end{array}$ & $\begin{array}{l}\text { Control } \\
270 \\
660\end{array}$ & $\begin{array}{r}- \\
8 \\
8\end{array}$ & $\begin{array}{l}2 \times 10^{-7} \\
1 \times 10^{-1} \\
5 \times 10^{-2}\end{array}$ \\
\hline
\end{tabular}

${ }^{a}$ The filtrates used here were taken from selected time points of the experiments of Fig. 2.

${ }^{b}$ The specific conjugative plasmid of the donor is indicated in parentheses. Donor cells were preincubated with recipient filtrate as described under Materials and Methods.

${ }^{c}$ The titers in each case were assayed using the corresponding donor strain as a responder.

part reflect the fact that the selectable determinant is located on the conjugative plasmid. (The other cases required selection of a determinant on a mobilized plasmid since no selectable markers existed on pPD1 or $\mathrm{pAM} \gamma 1$.)

As also shown in Table 3, there was an absence of mating enhancement using filtrates from late stationary OG1-10 cells, whereas the equivalent material from $\mathrm{JH} 2-2$ cells still provided significant mating enhancement. Thus there remains a good correlation between CIA activity and mating enhancement.

It is noteworthy that the CIA activity in filtrates is significantly stabilized as a result of boiling or even autoclaving (20 min). After such treatment, filtrates undergo no loss in activity upon storage for a number of weeks at $4^{\circ} \mathrm{C}$; whereas unheated samples undergo a significant loss in activity. We now routinely autoclave filtrates (for 20 $\min$ ), a step which probably inactivates degradative proteolytic enzymes. For the studies which follow, filtrates were prepared from cultures one or two generations prior to entrance into stationary phase.

\section{Differences in the Sensitivity of Donor Strains to Recipient Filtrate}

Different clinical isolates carrying conjugative plasmids were found to respond with different sensitivities to a single preparation of recipient filtrate. As shown in Table 4A, strain 39-5 was induced to clump by a filtrate of strain $\mathrm{JH} 2-2$ (plasmid free) that had been diluted up to 64-fold; whereas strain DS16 showed no response to this filtrate. (By the nature of the assay, the 
TABLE 4

Response of Different Strains to CIA ProducED BY JH2-2

\begin{tabular}{llc}
\hline $\begin{array}{l}\text { Strain } \\
\text { (host) }\end{array}$ & \multicolumn{1}{c}{ Plasmid content } & Response $^{a}$ \\
\hline A. & & \\
JH2-2 & None & $-(<2)$ \\
DS-5C1 & pAM $\gamma 1$, pAM $\alpha 1$ & 8 \\
5952 & pOB1, pOB2 & 2 \\
$39-5$ & pPD1, pPD2, pPD3, pPD4 & 64 \\
DS16 & pAD1, pAD2 & $-(<2)$ \\
& & \\
B. & & $-(<2)$ \\
JH2-2 & None & 4 \\
HD1 & pAM $\gamma 1$ & 4 \\
GD60 & pOB1 & 8 \\
GD50 & pPD1, pPD4 & $-(<2)$ \\
GD70 & pAD1 & \\
\hline
\end{tabular}

${ }^{a}$ The numbers indicate the reciprocal of the maximum dilution capable of inducing a clumping response.

highest concentration measured actually represents a two-fold dilution.) [Filtrates of another plasmid-free strain (OG1-10) did in fact induce DS16 with a response of 8.] Strains DS-5C1 and 5952 responded respectively to eight- and two-fold dilutions. The relationship of the clumping response to the conjugative plasmid is seen in Table 4B. Here isogenic strains (all involving a $\mathrm{JH}_{2}-2$ host) harboring $\mathrm{pAM} \gamma 1$, pOB1, or $\mathrm{pPD} 1$ were all found to respond to the $\mathrm{JH} 2-2$ filtrate, but again with differing levels of sensitivity. [Whereas neither GD70 nor DS16 (both carrying pAD1) responded to the JH2-2 filtrate, the data of Fig. 2 showed that strain OG1-50, a different host carrying the related plasmid pAD1::Tn917, did in fact respond to such a filtrate.] It is implied that the acquisition of a conjugative plasmid "shuts off" the synthesis of endogenous CIA (otherwise spontaneous clumping would be expected) and "sensitizes" the host to exogenous CIA. These and similar data using plasmid-containing isogenic derivatives of strain OG1-10 indicate that the level of sensitivity to a given filtrate depends on the specific plasmid as well as the host. As will be shown below, differing levels of sensitivity may also be due to the involvement of different CIA activities.

\section{Effect of Curing on Production and Response to CIA}

We have not been successful in eliminating (curing) pAM $\gamma 1$ or pPD1 from their original hosts (DS-5 and 39-5, respectively); thus, it has not been possible to determine if such curing results in a "turning on" of the synthesis of pheromone. We have, however, been able to cure pAD1 and pOB 1 from their original hosts (DS16 and 5952, respectively), and the effect is seen in Table 5. In each case the cured derivative produced a CIA activity to which the corresponding parent strain responded. Interestingly, both sets of parent and cured strains produced CIA activity to which strain 39-5 responded. Apparently the presence of pAD1 or pOB1 in these hosts resulted in a "shutoff" of production of the CIA to which the respective hemolysin plasmids responded, but did not prevent the strain from producing an additional activity specific for 39-5 (which harbors a different hemolysin plasmid).

\section{Evidence for Multiple CIAs}

Table 6 shows the response of $S$. faecalis donor strains carrying various conjugative plasmids to filtrates of JH2-2 strains carrying the respective plasmids (acquired by conjugation with the original clinical isolates). The introduction of a given conjugative plasmid into $\mathrm{JH} 2-2$ blocked production of CIA activity specific for the original host strain. For example, strain GD60 (harbors pOB1) produced no activity toward strain 5952 , the original source of the pOB 1 plasmid. However, in most cases the plasmid-carrying JH2-2 strains still produced activity toward strains carrying different plasmids. Thus, strain GD60 still produced full levels of CIA activity toward strains DS-5C1 and 39-5. The lack of response of DS16 to the filtrates is consistent 
TABLE 5

Production of Cia by Cured Strains ${ }^{a}$

\begin{tabular}{lcc}
\hline $\begin{array}{c}\text { Strain (plasmid content) tested } \\
\text { for response to CIA }\end{array}$ & $\begin{array}{c}\text { Strain (plasmid content) tested } \\
\text { for production of CIA }\end{array}$ \\
& DS16 (pAD1, pAD2) & DS16C1 (pAD2) \\
DS16 (pAD1, pAD2) & $-(<2)$ & 4 \\
DS16C1 (pAD2) & $-(<2)$ & $-(<2)$ \\
$39-5$ & 64 & 64 \\
& $5952(\mathrm{pOB} 1, \mathrm{pOB} 2)$ & $5952 \mathrm{C} 1(\mathrm{pOB} 2)$ \\
5952 (pOB1, pOB2) & $-(<2)$ & 4 \\
$5952 \mathrm{C} 1$ (pOB2) & $-(<2)$ & $-(<2)$ \\
$39-5$ & 64 & 64 \\
\hline
\end{tabular}

${ }^{a}$ Curing was carried out by culturing cells overnight at $45^{\circ} \mathrm{C}$. Hemolytic negative variants appeared at a frequency of 0.1 to $1.0 \%$. "Cured" cells were checked for absence of plasmid DNA by dye-CsCl centrifugation followed by examination of satellite DNA on sucrose density gradients.

${ }^{b}$ The numbers indicate the CIA titer of each filtrate.

with the data mentioned above in Table 3. It is noteworthy, however, that the presence of pAD1 in the JH2-2 host had no effect on the production of the other activities.

The response of strains carrying the pPD1 and $\mathrm{pAM} \gamma 1$ plasmids deserves further comment. The presence of pPD1 in $\mathrm{JH} 2-2$ blocked CIA production toward both 39-5 (harbors pPD1) and DS-5C1 (harbors pAM $\gamma 1$ ); whereas the presence of $\mathrm{pAM} \gamma 1$ in $\mathrm{JH} 2-2$ blocked production of activity toward DS-5C1 and resulted in a reduced level of activity toward 39-5. Strains carrying the pPD1 and $\operatorname{pAM} \gamma 1$ plasmids would appear to respond to different but perhaps related, CIAs. [In our original report (Dunny et al., 1978) we had noted that PAM $\gamma 1$, when harbored by either OG1-10 or JH2-2 did not totally "shutoff" the production of activity toward strain 39-5; this seemed puzzling at the time, since we had believed we were dealing with a single CIA activity.]

Insofar as the above data imply that a single recipient excretes several and perhaps many activities, a given CIA must now be defined by the plasmid system being used to determine its activity. We have chosen to identify the different activities

TABLE 6

Response of Various Strains to Different JH2-2 Hosts Carrying Different Conjugative Plasmids (Evidence for Multiple Cia Activities)

\begin{tabular}{lccccc}
\hline & \multicolumn{5}{c}{ Filtrates of JH2-2 hosts containing different plasmids ${ }^{a}$} \\
\cline { 2 - 6 } $\begin{array}{c}\text { Responder strain } \\
\text { (plasmid content) }\end{array}$ & $\begin{array}{c}\text { JH2-2 } \\
\text { (plasmid free) }\end{array}$ & $\begin{array}{c}\text { HD1 } \\
\text { (pAM } \gamma 1)\end{array}$ & $\begin{array}{c}\text { GD50 } \\
\text { (pPD1, pPD4) }\end{array}$ & $\begin{array}{c}\text { GD60 } \\
\text { (pOB1) }\end{array}$ & $\begin{array}{c}\text { GD70 } \\
\text { (pAD1) }\end{array}$ \\
\hline DS-5C1 (pAM $\gamma 1$, pAM $\alpha 1)$ & 8 & $-(<2)$ & $-(<2)$ & 8 & 8 \\
39-5 (pPD1, pPD2, pPD3, pPD4) & 64 & 4 & $-(<2)$ & 64 & 64 \\
5952 (pOB1, pOB2) & 8 & 8 & 8 & $-(<2)$ & 8 \\
DS16 (pAD1, pAD2) & $-(<2)$ & $-(<2)$ & $-(<2)$ & $-(<2)$ & $-(<2)$ \\
\hline
\end{tabular}

\footnotetext{
"The numbers indicate the CIA titer.
} 
by relating them to the plasmid originally used to identify them. For example, cPD1 refers to the CIA to which strains harboring pPD1 respond. Similarly, we identify other activities as, for example, cAM $\gamma 1$, cOB 1, and cAD1.

\section{On the Ubiquity of Sex Pheromones in S. faecalis}

One hundred clinical isolates of group D enterococci ( $S$. faecalis), characterized by their growth in bile esculine and $6.5 \%$ $\mathrm{NaCl}$, were obtained from University Hospital, Ann Arbor, Michigan. These strains were then catagorized with respect to their resistance to one or more of the following drugs: tetracycline [minimum inhibitory concentration (MIC) $>5 \mu \mathrm{g} / \mathrm{ml}$, erythromycin (MIC $>25 \mu \mathrm{g} / \mathrm{ml}$ ), streptomycin (MIC $>500 \mu \mathrm{g} / \mathrm{ml}$ ), and kanamycin (MIC $>500 \mu \mathrm{g} / \mathrm{ml}$ ). [Since S. faecalis usually have intrinsically high levels of resistance to aminoglycosides [i.e., MICs 25-100 $\mu \mathrm{g} / \mathrm{ml}$ (Matsen and Coghlan, 1972)], we arbitrarily chose $500 \mu \mathrm{g} / \mathrm{ml}$ or greater as being a level more likely to be associated with plasmid-related determinants.] The cells were then examined for their ability to respond (clump) when exposed to a filtrate of strain OG1-10 and also for their ability to excrete CIA activity capable of inducing responses in strains $39-5$ or OG1-12. As shown in Table $7,34 \%$ of the isolates underwent a typical clumping response when exposed to the OG1-10 filtrate; whereas 72 and $60 \%$ of the cells excreted CIA activity which induced clumping in 39-5 cells and OG1-12 cells, respectively. The ability to produce as well as respond to CIA was significantly more frequent among cells resistant to one or more drugs compared to sensitive cells. Of the cells resistant to all four drugs, $100 \%$ produced CIA activities detectible with at least one of the responder strains. The hemolytic strains also showed a high frequency of both production of and response (significantly different from nonhemolytics) to CIAs. (Of the 12 hemolytic strains, four were drug sensitive; while the other eight were resistant to one or more drugs.)

We point out here that the CIA activities which are excreted by a cell must be different from those to which the same cell responds. A response by a given strain

TABLE 7

Examination of 100 Clinical Isolates for Response to and Production of Cia

\begin{tabular}{|c|c|c|c|c|c|c|c|}
\hline & Total & $\begin{array}{c}\text { Sensitive } \\
\text { to } \\
\text { drugs }\end{array}$ & $\begin{array}{l}\text { Resistant to } \\
\text { one or more } \\
\text { drugs }\end{array}$ & $\begin{array}{l}\text { Resistant to } \\
\text { four drugs }\end{array}$ & $\begin{array}{l}\text { Hemo- } \\
\text { lytic }\end{array}$ & $\begin{array}{c}\text { Nonhemo- } \\
\text { lytic }\end{array}$ & $P^{a}$ \\
\hline \multirow{4}{*}{$\begin{array}{l}\text { Positive clumping } \\
\text { response to OG1- } \\
10 \text { filtrate }\end{array}$} & $34 / 100(34.0)^{b}$ & & & & & & \\
\hline & & $8 / 36(22.2)$ & $26 / 64(40.6)$ & & & & 0.048 \\
\hline & & $8 / 36(22.2)$ & & $6 / 11(54.5)$ & & & 0.050 \\
\hline & & & & & $9 / 12(75.0)$ & $25 / 88(28.4)$ & 0.003 \\
\hline \multicolumn{8}{|l|}{ Production of CIA } \\
\hline \multirow[t]{3}{*}{ Toward 39-5 } & $72 / 100(72.0)$ & $20 / 36(55.6)$ & $52 / 64(81.3)$ & & & & 0.006 \\
\hline & & $20 / 36(55.6)$ & & $11 / 11(100.0)$ & & & 0.004 \\
\hline & & & & & $10 / 12(83.3)$ & $62 / 88(70.5)$ & N.S. \\
\hline \multirow[t]{4}{*}{ Toward OG1-12 } & $60 / 100(60.0)$ & & & & & & \\
\hline & & $15 / 36(41.7)$ & $45 / 64(70.3)$ & & & & 0.005 \\
\hline & & $15 / 36(41.7)$ & & $10 / 11(90.9)$ & & & 0.004 \\
\hline & & & & & $9 / 12(75.0)$ & $51 / 88(58.0)$ & N.S. \\
\hline
\end{tabular}

a Significance was determined using the Fisher exact test for $2 \times 2$ contingency tables.

${ }^{b}$ Percentages in parentheses. 
implies the presence of a conjugative plasmid which in turn has shut down the endogenous production of its related CIA; whereas, other activities such as CAM $\gamma 1$ and $\mathrm{CPD} 1$ are still produced [as previously reported (Dunny et al., 1978), the presence of a nonconjugative plasmid pAM $\alpha 1$ had no effect on the production of CIA]. A cell which produces many different sex pheromones is "promiscuously receptive" and may thus acquire R-determinants (plasmids) from a broad selection of conjugative donors.

\section{DISCUSSION}

Our use of a microtiter system has greatly simplified the assay for CIA, making studies of the expression of this activity and the sensitivity of different "responder" cells relatively easy. The level of activity in culture filtrates was found to closely parallel cellular growth up to late log phase, at which time activity leveled off in the case of JH2-2 cells and decreased logarithmically (probably as a result of proteolytic activity) in the case of OG1-10 cells.

Of particular interest in the present study, was the observation that cells harboring a given conjugative plasmid continue to excrete CIA activities which "induce" strains harboring different conjugative plasmids. Thus, recipient cells must produce multiple CIA activities; and when a given conjugative plasmid is acquired, only the specifically related CIA is repressed (or inactivated). Since a given CIA activity is defined by the specific plasmid system in "responder" cells, we now identify such activities by relating them to the corresponding system first used to resolve them. For example, cAD1, cOB1, cPD1, and $\mathrm{cAM} \gamma 1$ refer to the activities to which cells respectively harboring pAD1, pOB1, pPD1, and pAM $\gamma 1$ respond. It will likely turn out that closely related plasmids will be found to make use of identical CIAs. Thus far, we have no solid information on the relative homologies or compatibilities of the four conjugative plasmids of interest here. (Preliminary studies suggest that $\mathrm{pAM} \gamma 1$ and $\mathrm{pAD} 1$ are in different compatibility groups.) On the basis of these findings, we are confident that we are dealing with a mating specific interaction.

Based on the information thus far obtained, we propose a model, shown in Fig. 3 , describing various relationships between conjugative plasmids, pheromones, and aggregation. The model depicts a plasmidfree recipient strain which produces two different pheromones (CIAs), $\mathrm{cA}$ and $\mathrm{cB}$. Two isogenic donor strains harboring the conjugative plasmids $\mathrm{pA}$ or $\mathrm{pB}$ are also shown. Plasmid $\mathrm{pA}$ determines the ability to respond to $\mathrm{CA}$ and, at the same time, through a regulatory (inhibiting) IcA gene, prevents production of endogenous $\mathrm{cA}$. (Alternatively an inactivation of $\mathrm{cA}$ could be involved.) Similarly, plasmid pB allows its host to respond to $\mathrm{cB}$ and prevents the production of endogenous $\mathrm{CB}$ through regulatory gene $\mathrm{IcB}$. The response of the donor cell to its corresponding exogenous CIA is depicted as the influencing of another regulatory substance (repressor or activator?), determined by gene $\mathrm{RcA}$ or $\mathrm{RcB}$, to activate the synthesis of the gene product(s) designated "aggregation substance" (AS). The latter material, which could be either plasmid or chromosomally determined (shown as plasmid-determined in the model), locates itself on the surface of the cell where it can now recognize "binding substance"' (BS). BS is a chromosomally determined substance which is located on the surface of both donors and recipients; thus, induced donors may aggregate with themselves as well as recipients.

The nature of AS and BS as well as their interaction remains to be determined. Preliminary studies have ruled out that AS is an excreted agglutinin; and it appears that aggregation requires calcium and phosphate ions (Yagi and Dunny, unpublished). Efforts to reveal pilus-like structures (corre- 


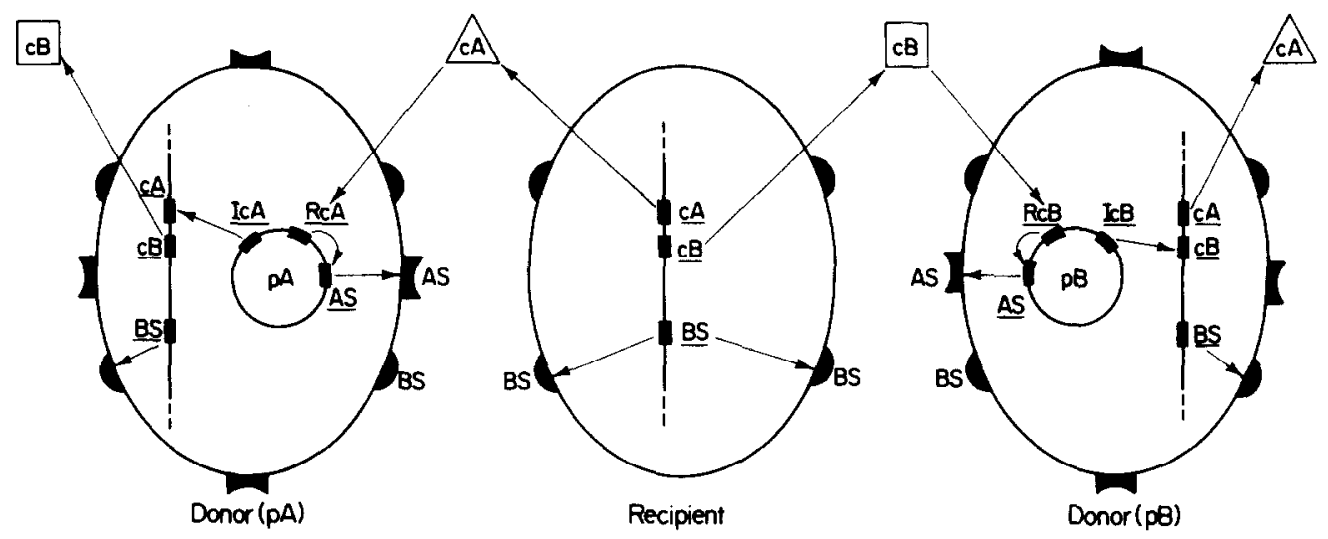

Fic. 3. A model showing various donor and recipient relationships with respect to the synthesis of and response to sex pheromones. $\underline{\mathrm{cA}}$ and $\underline{\mathrm{cB}}$ are the determinants of sex pheromones $\mathrm{cA}$ and $\mathrm{cB}$. BS represents the determinant for binding substance (BS) which is located on the cell surface. IcA and $\underline{I c B}$ are determinants for substances which repress (or inactivate) endogenous $\mathrm{CA}$ or $\mathrm{cB}$. $\underline{\mathrm{R} c \mathrm{~A}}$ and $\underline{\mathrm{R}} \mathrm{B}$ are determinants of regulatory proteins which respond respectively to $\mathrm{cA}$ or $\mathrm{cB}$ resulting in a "turning on" of the determinant $\underline{\mathrm{AS}}$ which produces aggregation substance (AS) which locates itself on the cell surface. Once a donor has responded to a sex pheromone, AS can now bind to BS which is located on recipients and also donors.

sponding to AS?) by electron microscopy have thus far been unsuccessful (Dunny, 1978).

It should be possible to obtain mutants which are defective in the various functions described in the model; and such mutants, in turn, should be helpful in further defining the overall system. While not shown in the model, it is likely that there is a specific plasmid-determined receptor site for the corresponding exogenous pheromone on the surface of the donor. Such a receptor substance might also facilitate the transport of the pheromone into the cell.

Preliminary studies involving fractionation of OG1-10 filtrates on Bio-Rad P2 acrylamide gel columns have indicated that cPD1 is relatively small and may represent a peptide with a molecular weight of 700-800 (Clewell et al., 1979). This substance also dramatically enhances mating potential of donors when exposed for $45 \mathrm{~min}$ prior to a 10-min mating. The synthesis of these molecules, therefore, may involve cleavages of larger molecules or perhaps a nonribosomal enzymatic assembly. It is conceivable that bacteria capable of producing a given pheromone cX may have never before encountered the corresponding plasmid $\mathrm{pX}$; and that $\mathrm{cX}$ actually plays another role or is a degradation product (e.g., in the synthesis of membrane or cell wall components). It may have been convenient then for plasmids to evolve in such a way as to take advantage of such molecules to facilitate their dissemination.

Examination of 100 clinical isolates of $S$. faecalis showed that the majority produced CIA activities. We also observed a significant correlation between drug resistance and the ability to produce and respond to CIAs. Conceivably, bacterial strains capable of producing pheromones are more likely to conjugally acquire $R$-plasmids. The production of pheromones by a cell may thus play a significant role in the evolution of bacterial drug resistance. It will be interesting to see if similar relationships hold with other bacteria. It has recently been shown that transfer of drug resistance can occur between Lancefield groups A, B, and $D$, as well as viridans streptococci (Van Embden et al., 1977, 1978; LeBanc et al., 1978; Hershfield, 1979). In most of these 
cases, cell-to-cell contact was facilitated by carrying out the matings on filter membranes; the involvement of pheromones remains to be determined.

Bezdek and Soska (1972) reported several years ago that Hfr strains of Salmonella typhimurium (LT2) appear to undergo a chemotactic response to a substance excreted by $\mathrm{F}^{-}$strains. Whereas chemotaxis is somewhat different from what we believe to occur in $S$. faecalis (the latter are nonmotile), the net result (i.e., the facilitation of cell-to-cell contact) would be the same.

It is noteworthy that CIA may in one sense bear some resemblance to competence factor in other systems. We have made numerous unsuccessful efforts to transform $S$. faecalis donors with plasmid DNA after treatment with CIA.

\section{ACKNOWLEDGMENTS}

We thank Paul Tomich, Yoshihiko Yagi, and Byron Brown for helpful discussions and assistance in certain aspects of this work; Karen Kalwaic of University Hospital (Ann Arbor) for providing us with the clinical isolates; and Charles Kowalski for assistance in the statistical analyses. This work was supported by Public Health Research Grant DE02731 from the National Institute of Dental Research and Grant KO4 A100061 (Research Career Development Award to DBC) from the National Institute of Allergy and Infectious Diseases. G.M.D. was supported by a National Science Foundation Graduate Fellowship and an F. G. Novy Fellowship from the Department of Microbiology, University of Michigan School of Medicine.

\section{REFERENCES}

Bezdek, M., and Saska, J. (1972). Sex-determined chemotaxis in Salmonella typhimurium LT2. Folia Microbiol. 17, 366-369.

Clewell, D., Dunny, G., Brown, B., Craig, R., AND YAGI, Y. (1979). Sex pheromones in Streptococcus faecalis. In "Pathogenic Streptococci" (M.T. Parker, ed.). Reedbooks, Chertsey, Surry, in press.

Clewell, D., Yagi, Y., Damle, A., ANd AN, F. 1978. Plasmid-related gene amplification in Streptococcus faecalis. In "Microbiology-1978," (D. Schlessinger, ed.) pp. 29-32. Amer. Soc. for Microbiology, Washington, D. C.

Clewell, D. B., YaGi, Y, Dunny, G. M., AND
Schultz, S. K. (1974). Characterization of three plasmid deoxyribonucleic acid molecules in a strain of Streptococcus faecalis : Identification of a plasmid determining erythromycin resistance. $J$. Bacteriol. 117, 283-289.

Dunny, G. M. (1978). Ph.D. Thesis, University of Michigan.

Dunvy, G. M., Brown, B. L., ANd Clewell, D. B. (1978). Induced cell aggregation and mating in Streptococcus faecalis: Evidence for a bacterial sex pheromone. Proc. Nat. Acad. Sci. USA. 75, 3479-3483.

Dunny, G. M., AND Clewell, D. B. (1975). Transmissible toxin (hemolysin) plasmid in Streptococcus faecalis and its mobilization of a noninfectious drug resistance plasmid. J. Bacteriol. 124, $784-790$.

Franke, A. E., Dunny, G. M., Brown, B. L., An, F. Oliver, D. R., Damle, S. P., AND Clewell, D. B. (1978). Gene transfer in Streptococcus faecalis: Evidence for mobilization of chromosomal determinants by transmissible plasmids. In "Microbiology -1978," (D. Schlessinger, ed.), pp. 45-47. Amer. Soc. for Microbiology, Washington, D. C.

Hershfield, V. (1979). Plasmids mediating multiple drug resistance in group B streptococcus: Transferability and molecular properties. Plasmid, 2, 137- 149 .

Jacob, A. E., Douglas, G. J., ANd HobBs, S. J. (1975). Self-transferable plasmids determining the hemolysin and bacteriocin of Streptococcus faecalis var. zymogenes. J. Bacteriol. 121, 863-872.

JaCOB, A. E., AND HoBbs, S. J. (1974). Conjugal transfer of plasmid-borne multiple antibiotic resistance in Streptococcus faecalis var. zymogenes. J. Bacteriol. 117, 360-372.

LeBlanc, D. J., Hawley, R. J., Lee, L. N., and St. Martin, E. J. (1978). "Conjugal" transfer of plasmid DNA among oral streptococci. Proc. Nat. Acad. Sci. USA. 75, 3484-3487.

MARder, H., AND KaYSER, F. (1977). Transferable plasmids mediating multiple-antibiotic resistance in Streptococcus faecalis subsp. liquefaciens. Antimicrob. Ag. Chemother. 12, 261-269.

Matsen, J., and Coghlan, C. (1972). Antibiotic testing and susceptibility patterns of streptococci. In "Streptococci and Streptococcal Diseases" (L. Wannemaker and J. Matsen, eds.) pp. 189-204. Academic Press, New York.

Oliver, D. R., Brown, B. L., ANd Clewell, D. B. (1977a). Characterization of plasmids determining hemolysin and bacteriocin production in Streptococcus faecalis 5952. J. Bacteriol. 130, 948-950.

Oliver, D. R., Brown, B. L., AND Clewell, D. B. (1977b). Analysis of plasmid deoxyribonucleic acid in a cariogenic strain of Streptococcus faecalis: An approach to identifying genetic determinants on cryptic plasmids. J. Bacteriol. 130, 759 - 765. 
Rosan, B., AND Williams, N. (1964). Hyaluronidase production by oral enterococci. Arch. Oral Biol. 9, 291-298.

Tomich, P., AN, F., ANd Clewell, D. (1978). A transposon (Tn917) in Streptococcus faecalis which exhibits enhanced transposition during induction of drug resistance. Cold Spring Harbor Symp. Quant. Biol., in press.

Tomura, T., Hirano, T., Ito, T., and Yoshioka, M. (1973). Transmission of bacteriocinogenicity by conjugation in group D streptococci. Japan J. Microbiol. 17, 445-452.

Van Embden, J., Engel, H., and Van Klingeren,
B. (1977). Drug resistance in group D streptococci of clinical and non-clinical origin: prevalence, transferability and plasmid properties. Antimicrob. Ag. Chemother. 11, 925-932.

Van Embden, J., Soedirman, N., ANd Engel, H. (1978). Transferable drug resistance to group $A$ and group B streptococci. Lancet 1, 655-656.

WAGNER, M. (1973). Relationship of specific antibacterial agglutinins in saliva to dental caries in gnotobiotic rats. In "Germfree Research" (J. B. Heneghan, ed.), pp. 211-216. Academic Press, London/New York. 